\title{
Consumption of strawberries on a daily basis increases the non-urate 2,2-diphenyl-1- picryl-hydrazyl (DPPH) radical scavenging activity of fasting plasma in healthy subjects
}

\author{
Anna Prymont-Przyminska, ${ }^{1}$ Anna Zwolinska, ${ }^{2}$ Agata Sarniak, ${ }^{1}$ Anna Wlodarczyk, ${ }^{3}$ Maciej Krol, ${ }^{3}$ Michal Nowak, ${ }^{4}$ \\ Jeffrey de Graft-Johnson, ${ }^{5}$ Gianluca Padula, ${ }^{6}$ Piotr Bialasiewicz, ${ }^{3}$ Jaroslaw Markowski, ${ }^{7}$ Krzysztof P. Rutkowski ${ }^{7}$ \\ and Dariusz Nowak ${ }^{8, *}$ \\ ${ }^{1}$ Department of General Physiology, ${ }^{2}$ Cell-to-cell Communication Department, ${ }^{3}$ Department of Sleep Medicine and Metabolic Disorders \\ and ${ }^{8}$ Department of Clinical Physiology, Medical University of Lodz, Mazowiecka 6/8, 92-215 Lodz, Poland \\ ${ }^{4}$ Medical Physics Faculty, University of Lodz, Lodz, Poland \\ ${ }^{5}$ Thoracic Innovation, Fort Lauderdale, Florida, USA \\ ${ }^{6}$ Academic Laboratory of Movement and Human Physical Performance, Medical University of Lodz, Lodz, Poland \\ ${ }^{7}$ Research Institute of Horticulture, Division of Pomology, Fruit Storage and Processing Department, Skierniewice, Poland
}

(Received 16 October, 2013; Accepted 13 February, 2014; Published online 10 May, 2014)

\begin{abstract}
Strawberries contain anthocyanins and ellagitanins which have antioxidant properties. We determined whether the consumption of strawberries increase the plasma antioxidant activity measured as the ability to decompose 2,2-diphenyl-1-picrylhydrazyl radical (DPPH) in healthy subjects. The study involved 10 volunteers (age $41 \pm 6$ years, body weight $74.4 \pm 12.7 \mathrm{~kg}$ ) that consumed $500 \mathrm{~g}$ of strawberries daily for 9 days and 7 matched controls. Fasting plasma and spot morning urine samples were collected at baseline, during fruit consumption and after a 6 day wash-out period. DPPH decomposition was measured in both deproteinized native plasma specimens and pretreated with uricase (non-urate plasma). Twelve phenolics were determined with HPLC. Strawberries had no effect on the antioxidant activity of native plasma and circulating phenolics. Non-urate plasma DPPH decomposition increased from $5.7 \pm 0.6 \%$ to $6.6 \pm 0.6 \%, 6.5 \pm 1.0 \%$ and $6.3 \pm 1.4 \%$ after 3,6 and 9 days of supplementation, respectively. The washout period reversed this activity back to $5.7 \pm 0.8 \%(p<0.01)$. Control subjects did not reveal any changes of plasma antioxidant activity. Significant increase in urinary urolithin $A$ and 4-hydroxyhippuric (by 8.7- and 5.9-times after 6 days of supplementation with fruits) was noted. Strawberry consumption can increase the non-urate plasma antioxidant activity which, in turn, may decrease the risk of systemic oxidants overactivity.
\end{abstract}

Key Words: strawberry, plasma antioxidant activity, dietary intervention, polyphenols

S trawberry (Fragaria $X$ ananassa Duch) is a very popular species cultivated in numerous countries for its fruits (culinary term) which are frequently consumed either fresh, frozen or as an additive to dairy products. Regular consumption of strawberries can have potential health promoting effects. This includes the reduction of atherosclerotic markers in subjects with metabolic syndrome ${ }^{(1,2)}$ decrease in low-density lipoprotein (LDL) peroxidative damage $\mathrm{e}^{(1,3,4)}$ and augmentation of plasma antioxidant activity. ${ }^{(5)}$ These beneficial effects can be attributed to the presence of numerous phytochemicals, mostly polyphenols with antioxidant and anti-inflammatory properties. ${ }^{(6,7)}$ The most important are anthocyanins, namely pelargonidin-3-glucoside, cyanidin-3glucoside, pelargonidin-3-rutoside and pelargonidin-3-malonylglucoside, as well as ellagic acid and ellagitannins. ${ }^{(6,7)}$ Clinical studies with healthy subjects having a single portion of 200 to $750 \mathrm{~g}$ of strawberries revealed a peak in anthocyanin metabolites in plasma between 2 and $3 \mathrm{~h}$ after fruit consumption with subsequent normalization within an additional $6 \mathrm{~h}$ period. ${ }^{(8,9)}$ Within $6 \mathrm{~h}$ after consuming strawberries, the majority of anthocyanin metabolites were excreted in urine. ${ }^{(9,10)}$ These results suggest that a considerable amount of effects obtained from eating strawberries evident as a rise in circulating phenolics (e.g., augmentation of plasma antioxidant activity) is not observed after several hours in fasting plasma. However, results from studies devoted to the antioxidant effect of regular consumption of strawberries contradict this suggestion. ${ }^{(3,5)}$ Studies revealed an elevated ferric reducing ability (FRAP) ${ }^{(5)}$ and increased LDL resistance to $\mathrm{Cu}^{2+}$ induced oxidation $^{(3)}$ in fasting plasma collected several hours subsequent to the last strawberry meal. Moreover, increased FRAP persisted for 30 days after interruption of strawberry consumption. ${ }^{(5)}$ Therefore, to solve these discrepancies we examined the effects exerted on the antioxidant activity of fasting plasma (DDPH radical decomposition and FRAP) and the levels of key metabolites from anthocyanins and ellagitanins in fasting plasma and spot urine in healthy subjects consuming a daily dose of $500 \mathrm{~g}$ of strawberries for nine days.

\section{Material and Methods}

Strawberry. The strawberry "Honeoye" fruits were harvested at commercial maturity at a plantation managed according to organic standards located near Skierniewice (Poland). Strawberries were washed, destemmed, mixed to achieve a uniform experimental sample, frozen, disintegrated at $-25^{\circ} \mathrm{C}$, then packed in polyethylene (PE) bags in quantities of $500 \pm 1 \mathrm{~g}$ and stored (not exceeding 3 months) at the same temperature $\left(-25^{\circ} \mathrm{C}\right)$ until further consumption (Table 1).

Study population. The study group involved 10 volunteers ( 6 men, mean age $41 \pm 6$ years, mean body weight $74.4 \pm 8.7 \mathrm{~kg}$, mean body mass index $24.1 \pm 2.6 \mathrm{~kg} / \mathrm{m}^{2}$ ). The inclusion criteria were an age between 35 and 50 years and a written informed consent before entering the study. The control group consisted of

*To whom correspondence should be addressed. E-mail: dariusz.nowak@umed.lodz.pl 
Table 1. Characteristics of the studied strawberry fruit "Honeoye"

\begin{tabular}{|c|c|}
\hline Dry matter (\%) & $11.2 \pm 1.4$ \\
\hline Saccharose $(\mathrm{g} / 100 \mathrm{~g})$ & $0.37 \pm 0.01$ \\
\hline Glucose $(\mathrm{g} / 100 \mathrm{~g})$ & $3.52 \pm 1.3$ \\
\hline Fructose $(\mathrm{g} / 100 \mathrm{~g})$ & $3.90 \pm 0.7$ \\
\hline Ascorbic acid (mg/100 g) & $42.7 \pm 1.1$ \\
\hline Malic acid $(\mathrm{mg} / 100 \mathrm{~g})$ & $244 \pm 5$ \\
\hline Citric acid (mg/100 g) & $898 \pm 29$ \\
\hline Total anthocyanins $(\mathrm{mg} / 100 \mathrm{~g})$ & $108.9 \pm 3.5$ \\
\hline Cyanidin 3-O-glucoside (mg/100 g) & $1.1 \pm 0.0(2.4)$ \\
\hline Pelargonidin 3-O-glucoside (mg/100 g) & $91.3 \pm 2.9(210.8)$ \\
\hline Pelargonidin 3-O-rutinoside $(\mathrm{mg} / 100 \mathrm{~g})$ & $2.7 \pm 0.1(4.7)$ \\
\hline Cyanidin 3-O-(6"-malony-glucoside) (mg/100 g) & $0.2 \pm 0.0(0.4)$ \\
\hline Pelargonidin 3-O-(6"-malony-glucoside) (mg/100 g) & $12.7 \pm 0.4(24.5)$ \\
\hline Total phenolic compounds $(\mathrm{mg} / 100 \mathrm{~g})$ & $253 \pm 5$ \\
\hline Chlorogenic acid and derivatives $(\mathrm{mg} / 100 \mathrm{~g})$ & $0.39 \pm 0.01(1.1)^{*}$ \\
\hline $\mathrm{p}$-Coumaric acid and derivatives $(\mathrm{mg} / 100 \mathrm{~g}$ ) & $5.98 \pm 0.10(36.5)^{* *}$ \\
\hline Ellagic acid $(\mathrm{mg} / 100 \mathrm{~g})$ & $17.3 \pm 0.4(57.3)$ \\
\hline Quercetin glycosides $(\mathrm{mg} / 100 \mathrm{~g})$ & $4.30 \pm 0.09$ \\
\hline Keampferol glycosides $(\mathrm{mg} / 100 \mathrm{~g})$ & $4.41 \pm 0.04$ \\
\hline Catechin $(\mathrm{mg} / 100 \mathrm{~g})$ & $1.8 \pm 0.2(6.2)$ \\
\hline Epicatechin (mg/100 g) & $1.5 \pm 0.2(5.2)$ \\
\hline Procyanidins (mg/100 g) & $108 \pm 4$ \\
\hline
\end{tabular}

Results obtained from 10 separate measurements with randomly collected specimens of disintegrated fruits just before packing to PE bags. In parentheses, content expressed in $\mu$ moles per $100 \mathrm{~g}$ of strawberries. $*, * *$ calculation was based on the molecular weight of chlorogenic acid and $\mathrm{p}$-coumaric acid, respectively. The decrease in the content of polyphenols in the strawberry pulp during 3 month storage at $-25^{\circ} \mathrm{C}$ did not exceeded $4 \%$ for all compounds specified in the table.

7 subjects ( 4 men, mean age $46 \pm 6$ years, mean body weight $77.4 \pm 6.8 \mathrm{~kg}$, mean body mass index $25.6 \pm 1.6 \mathrm{~kg} / \mathrm{m}^{2}$ ). All volunteers were members of the scientific staff of the Medical University of Lodz. They were apparently healthy nonsmokers and agreed to comply with dietary instructions related to their participation in the study. The exclusion criteria included: pregnancy, alcohol and illicit drug abuse, fructose intolerance, strawberry hypersensitivity, any history of infectious and inflammatory diseases, use of any vitamins, food supplements or any systemic treatment with antibiotics within 3 months prior to the study.

Study protocol. They study had an open label with a run-in and wash-out period design and consisted of 7 visits on the 0th, $3 \mathrm{rd}$, 6th, 9th, 12th, 15th and the 21st day of the trial. During the study period (21 days), volunteers (study group and control group) did not consume any fruits (fresh, frozen, dried, canned), products containing fruits (e.g., jams, yogurts), fruit juices, nuts, chocolate, coffee, cocoa, wine and beer. Consumption of tea was limited to 3 cups per day. Ingestion of vegetables was allowed and volunteers were asked to maintain it on the usual level during the study period. After a 6 day run-in period, volunteers from study group commenced (visit on the 6th day) a daily consumption of $500 \mathrm{~g}$ of strawberries (unfrozen at room temperature and consumed between 11.00-14.00 h) for 9 days pending a visit on the 15 th day. The wash-out period from the 15th day visit lasted 6 days (visit on the $21 \mathrm{st}$ day). Spot morning urine $(10 \mathrm{ml})$ was collected between 6:30-7:30 a.m. Visits took place between 8:30-9:30 a.m. Fasting venous blood $(10 \mathrm{ml})$ was collected (EDTA-K2 Vacutest tubes) then centrifuged $\left(10 \mathrm{~min}, 1,500 \times \mathrm{g}, 4^{\circ} \mathrm{C}\right)$. Obtained plasma was stored (not exceeding 3 months) at $-80^{\circ} \mathrm{C}$ until assay. Urine was also centrifuged and stored under equal conditions. At the first visit, volunteers received a diary card to record daily consumption of selected food products and beverages rich in polyphenols and all complaints, especially related to inflammatory and infectious disorders, as well as any medications and supplements that may have affected oxidant/antioxidant balance in the blood. This was reviewed by investigators in respect to continuation or a subject withdrawal from the study during each subsequent visit. Control subjects were asked to obey all dietary restrictions, however, they did not consume strawberries. The Medical University of Lodz Ethics Committee approved the study protocol (approval RNN/62/09/KE).

Determination of selected phenolics in human plasma and urine. All chemicals, buffers and water used throughout the study were of HPLC grade. 3,4-dihydroxyphenylacetic acid, dihydrocaffeic acid, vanillic acid, caffeic acid and homovanillic acid were determined by HPLC with electrochemical detection (HPLC-ECD) while hippuric acid, 3-hydroxyhippuric, 4-hydroxyhippuric, 3,4-dihydroxybenzoic acid, chlorogenic acid, ellagic acid and urolithin A were determined by HPLC with UV/VIS detection (HPLC-UV/VIS). HPLC-ECD: the equipment was composed of P580 HPLC pump (Dionex, Sunnyvale, CA); Hypersil BDS C18 column $(150 \times 2.1 \mathrm{~mm}$ ID, $3-\mu \mathrm{m}$ particles $)$, an electrochemical detector with a flow-through detection cell equipped with a glass carbon electrode, and an $\mathrm{Ag} / \mathrm{AgCl}$ reference one, set at $+0.82 \mathrm{~V}$ with a working temperature of $32^{\circ} \mathrm{C}$ (Decade, Antec Leyden, Netherlands), degasser (Biotech model 2003), universal chromatography interface (UCI-100 Dionex) and a 20$\mu \mathrm{l}$ manual injector. The mobile phase was prepared by the addition of $0.75 \mathrm{~g} \mathrm{KH}_{2} \mathrm{PO}_{4}, 40 \mathrm{mg}$ EDTA, $3 \mathrm{ml} 1 \mathrm{~mol} / \mathrm{L} \mathrm{H}_{3} \mathrm{PO}_{4}$ and $45 \mathrm{ml}$ of methanol to $440 \mathrm{ml}$ of water, the $\mathrm{pH}$ was then adjusted to 2.80 with a concentrated $\mathrm{CH}_{3} \mathrm{COOH}$ with its volume filled up to $500 \mathrm{ml}$ with water. HPLC-UV/VIS: the equipment was composed of an P580 HPLC pump; Phenomenex HPLC column (Synergi $4 \mu \mathrm{m}$ Fusion - RP 80 A), column oven (STH 585 Dionex) set at a working temperature of $25^{\circ} \mathrm{C}$, a diode array detector (wavelengths 210, 280 and $325 \mathrm{~nm}$, UVD340 U Dionex) and an automated sample injector (ASI-100 Dionex). Plasma samples $(0.5 \mathrm{ml})$ were mixed with $50 \mu \mathrm{l}$ of a $0.78 \mathrm{M}$ acetate buffer (pH 5.2), $25 \mu \mathrm{l}$ of a $20 \%$ ascorbic acid solution, $10 \mu \mathrm{l}$ of a $2 \mathrm{mg} / \mathrm{L}$ fisetyn solution, $10 \mu$ of $\beta$-glucuronidase (from bovine liver, type B-3) in a $0.1 \mathrm{M}$ acetate buffer $(4,000 \mathrm{U} / \mathrm{ml}, \mathrm{pH} 5.2)$, and $10 \mu \mathrm{l}$ of sulphatase (from Helix pomatia, type $\mathrm{H}-1$ ) solution in a $0.1 \mathrm{M}$ acetate buffer (1,028 U/ml, pH 5.2) (Sigma-Aldrich Chemical, St. Louis, MO) and incubated for $60 \mathrm{~min}$ at $37^{\circ} \mathrm{C}$. Then, $0.5 \mathrm{ml}$ of a $1 \mathrm{M}$ solution of phosphoric acid was added. The sample was again incubated for $10 \mathrm{~min}$ at $37^{\circ} \mathrm{C}$, then mixed with $0.5 \mathrm{ml}$ of water and poured into a Speedisk ${ }^{\circledR}$ Column $\mathrm{H}_{2} \mathrm{O}$-Phobic DVB ( $3 \mathrm{ml}$ Solid Phase Extraction Column $50 \mathrm{mg}$ per column, $15 \mu \mathrm{m}$ particle diameter J.T. Baker, Phillipsburg, NJ) preconditioned with $1 \mathrm{ml}$ of methanol and $0.5 \mathrm{ml}$ of water. The column was washed 3 times with $0.5 \mathrm{ml}$ of water, dried under a vacuum, and eluted with $0.4 \mathrm{ml}$ of methanol. Then $50 \mu \mathrm{l}$ of the eluate was mixed with $450 \mu \mathrm{l}$ of mobile phase and $20 \mu \mathrm{l}$ samples of these solutions were subjected to isocratic analysis with HPLC-ECD. The flow rate of the mobile phase was kept constant at $0.20 \mathrm{ml} / \mathrm{min}$ and the total run time was $90 \mathrm{~min}$. Samples of methanol eluate from Speedisk ${ }^{\mathbb{R}}$ Column $(5 \mu \mathrm{l})$ were also analyzed with gradient elution HPLCUV/VIS and flow rate $0.25 \mathrm{ml} / \mathrm{min}$. The mobile phase consisted of solvent $\mathrm{A}\left(0.05 \%\right.$ aqueous solution of $\left.\mathrm{H}_{3} \mathrm{PO}_{4}\right)$ and solvent $\mathrm{B}$ $\left(0.05 \%\right.$ solution of $\mathrm{H}_{3} \mathrm{PO}_{4}$ in acetonitrile). The system was ran with a gradient program: 4-15\% B (v/v) (0-8 min), 15-40\% B (15 min), 40-50\% B (6 min), 50\% B (1 min), 50-4\% B (1 min), and $4 \% \mathrm{~B}(10 \mathrm{~min})$. Urine samples $(4 \mathrm{ml})$ were mixed with $0.5 \mathrm{ml}$ of $0.78 \mathrm{M}$ acetate buffer $(\mathrm{pH} 5.2), 40 \mu \mathrm{l}$ of $\beta$-glucuronidase solution in $0.1 \mathrm{M}$ acetate buffer $(4,000 \mathrm{U} / \mathrm{ml})$, and $40 \mu \mathrm{l}$ of sulphatase solution in $0.1 \mathrm{M}$ acetate buffer $(1,028 \mathrm{U} / \mathrm{ml})$ and incubated for $60 \mathrm{~min}$ at $37^{\circ} \mathrm{C}$. Then, $0.5 \mathrm{ml}$ of $1 \mathrm{M}$ solution of phosphoric acid was added. The sample was again incubated for $10 \mathrm{~min}$ at $37^{\circ} \mathrm{C}$, mixed with $0.5 \mathrm{ml}$ of water and poured into a Bakerbond SPE C18 $500 \mathrm{mg} / 3 \mathrm{ml}$ column (J.T. Baker, Phillipsburg, NJ) preconditioned with $3 \mathrm{ml}$ of methanol and $10 \mathrm{ml}$ of water. The column was washed 2 times with $1.5 \mathrm{ml}$ of water and then eluted 
Table 2. The detection and determination limits of phenolics measurement with HPLC and the recovery from SPE column

\begin{tabular}{|c|c|c|c|c|}
\hline \multirow{2}{*}{ Analyzed compound } & \multirow{2}{*}{$\begin{array}{l}\text { Detection limit } \\
(\mu \mathrm{mol} / \mathrm{L})\end{array}$} & \multirow{2}{*}{$\begin{array}{l}\text { Determination limit } \\
(\mu \mathrm{mol} / \mathrm{L})\end{array}$} & \multicolumn{2}{|c|}{ Recovery from SPE column (\%) } \\
\hline & & & Plasma & Urine \\
\hline DOPAC $^{A}$ & $0.03 \pm 0.00$ & $0.05 \pm 0.01$ & $96 \pm 5$ & $98 \pm 4$ \\
\hline Vanillic acidA & $0.02 \pm 0.00$ & $0.08 \pm 0.01$ & $97 \pm 4$ & $67 \pm 5$ \\
\hline Caffeic acid ${ }^{\mathrm{A}}$ & $0.01 \pm 0.00$ & $0.03 \pm 0.00$ & $98 \pm 5$ & $68 \pm 6$ \\
\hline Dihydrocaffeic ${ }^{A}$ & $0.02 \pm 0.00$ & $0.08 \pm 0.01$ & $98 \pm 4$ & $66 \pm 5$ \\
\hline Homovanillic acidA & $0.01 \pm 0.00$ & $0.03 \pm 0.00$ & $96 \pm 5$ & $64 \pm 6$ \\
\hline Chlorogenic acid ${ }^{\mathrm{B}}$ & $1.10 \pm 0.07$ & $3.34 \pm 0.11$ & ND & $100 \pm 4$ \\
\hline Hippuric acid ${ }^{B}$ & $2.60 \pm 0.11$ & $7.90 \pm 0.13$ & $99 \pm 6$ & $85 \pm 6$ \\
\hline 4-hydroxyhippuric acidB & $1.19 \pm 0.05$ & $3.62 \pm 0.09$ & $93 \pm 5$ & $96 \pm 4$ \\
\hline 3-hydroxyhippuric acid ${ }^{B}$ & $0.70 \pm 0.05$ & $2.11 \pm 0.12$ & $99 \pm 4$ & $94 \pm 5$ \\
\hline Ellagic acid ${ }^{B}$ & $1.21 \pm 0.09$ & $3.65 \pm 0.15$ & $97 \pm 6$ & $41 \pm 6$ \\
\hline Urolithin $A^{B}$ & $0.36 \pm 0.07$ & $1.10 \pm 0.06$ & $67 \pm 4$ & $97 \pm 6$ \\
\hline 3,4-dihydroxybenzoic acid ${ }^{B}$ & $1.39 \pm 0.06$ & $4.21 \pm 0.18$ & $100 \pm 6$ & $80 \pm 5$ \\
\hline
\end{tabular}

SPE, solid phase extraction; DOPAC, 3,4-dihydroxyphenylacetic acid; ${ }^{A}$ determined with HPLC-ECD, ${ }^{\mathrm{B}}$ determined with HPLC-UV/VIS. ND, not determined. Values represent the mean of 3 series of experiments.

with $9 \mathrm{ml}$ of $0.1 \mathrm{M}$ acetate buffer $(\mathrm{pH}=5.2)$, dried under a vacuum, and eluted again with $3.0 \mathrm{ml}$ of methanol. Caffeic acid, homovanillic acid and ellagic acid were determined in methanol eluate while the remaining compounds were determined in the acetate buffer eluate. Two hundred $\mu$ l of acetate buffer eluate was mixed with $200 \mu \mathrm{l}$ of mobile phase (solvent A) and $5 \mu 1$ of this solution was analyzed with HPLC-UV/VIS: flow rate $0.25 \mathrm{ml} / \mathrm{min}$, and gradient program: $4-10 \% \mathrm{~B}(\mathrm{v} / \mathrm{v})(0-8 \mathrm{~min}), 10$ $40 \% \mathrm{~B}(12 \mathrm{~min}), 40 \% \mathrm{~B}(3 \mathrm{~min}), 40-4 \% \mathrm{~B}(2 \mathrm{~min})$, and $4 \% \mathrm{~B}$ (10 min). Gradient program: 4-15\% B (v/v) (0-8 min), $15-40 \%$ B (19 min), 40-50\% B (6 min), 50\% B (1 min), 50-4\% B (1 min), and $4 \% \mathrm{~B}(10 \mathrm{~min})$ was instead used for analysis of $5 \mu \mathrm{l}$ of methanol eluate. HPLC-ECD: $10 \mu \mathrm{l}$ of acetate buffer eluate or methanol eluate was mixed with $490 \mu \mathrm{l}$ of mobile phase. $20 \mu \mathrm{l}$ of this solution was analyzed as described for plasma specimens. Chromeleon software (Dionex, Sunnyvale, CA) was used for chromatographic data collection and calculation of concentrations of phenolics. Identification of particular compounds were conducted on the basis of their spectral characteristics and retention times in comparison to corresponding standard substances. All standards were from Sigma-Aldrich Chemie GmbH (Steinheim, Germany) or from Fluka Sigma-Aldrich (Buchs, Steinheim, Germany) except for urolithin A that was a generous gift from professor B. Krol (Institute of Chemical Technology of Food, Technical University of Lodz). Individual results were obtained as a mean from duplicate measurements and expressed in $\mu \mathrm{M}$ and $\mu \mathrm{mol} / \mathrm{g}$ of creatinine. The detection and determination limits and recovery of phenolics from SPE columns are shown in Table 2.

Measurement of plasma DPPH radical- scavenging activity. Plasma DPPH radical-scavenging activity (DPPH test) was determined following our procedure ${ }^{(11)}: 5 \mu \mathrm{l}$ of $10 \mathrm{mM}$ of a DPPH radical solution in methanol was added to a cuvette containing $0.970 \mathrm{ml}$ of methanol and continuously stirred. Then, after a $3 \mathrm{~min}$ incubation period at $20^{\circ} \mathrm{C}$, the baseline absorbance at wavelength $517 \mathrm{~nm}$ (A517) was measured with an Ultrospec III, using SpectroKinetics software (LKB Biochrom Pharmacia, Cambridge, England). Afterward, $25 \mu \mathrm{l}$ of deproteinized plasma was added, mixed, and the A517 decrease related to the DPPH radical decomposition over $30 \mathrm{~min}$ of incubation period was then recorded. Negative control samples were $25 \mu \mathrm{l}$ of $9.50 \mathrm{M}$ acetonitrile solution. All individual results were obtained from duplicate measurements and plasma scavenging effect $(\mathrm{Sc} \%)$ was calculated according to the formula $\mathrm{Sc} \%=(1-\mathrm{A} 517$ plasma sample/A517 negative control) $\times 100 \%$. The coefficient of variation was $4.2 \%$ and detection limit was $0.50 \%$ of the initial amount of decomposed DPPH radical over 30 min of incubation. ${ }^{(11)}$ Plasma specimens were deproteinized by mixing with an equal volume of acetonitrile. They were centrifuged $\left(10 \mathrm{~min}, 4^{\circ} \mathrm{C}, 9,500 \times \mathrm{g}\right)$ after 2 min incubation at $20^{\circ} \mathrm{C}$. Supernatant (deproteinized plasma) was collected and stored at $-80^{\circ} \mathrm{C}$ until assay. Part of plasma samples $(200 \mu \mathrm{l})$ was incubated with $1.2 \mathrm{U} / \mathrm{ml}$ uricase and $24 \mathrm{U} / \mathrm{ml}$ catalase (Sigma-Aldrich Chemical, St. Louis, MO) for $10 \mathrm{~min}$ at $37^{\circ} \mathrm{C}$ and then deproteinized with acetonitrile. Preliminary experiments with six plasma specimens with uric acid concentration ranging from 5.2 to $6.8 \mathrm{mg} / \mathrm{dl}$ revealed complete decomposition of uric acid already after $5 \mathrm{~min}$ from uricase addition. Catalase was added for rapid decomposition of $\mathrm{H}_{2} \mathrm{O}_{2}$ (generated during uricasecatalyzed oxidation of uric acid by oxygen) to prevent suppression of plasma antioxidant activity. Catalase alone did not change plasma DPPH radical scavenging activity.

Other determinations. Plasma uric acid and urinary creatinine were determined with an Alpha Diagnostics Creatinine kit and an Alpha Diagnostics Uric Acid kit (Alpha Diagnostics, Warsaw Poland). Total phenolic compound concentrations in plasma and urine was measured by the Folin-Ciocalteau method ${ }^{(12)}$ and expressed in catechin equivalent $\mu \mathrm{mol} / 1$ and $\mu \mathrm{mol} / \mathrm{g}$ of creatinine, respectively. Strawberry phenolics were determined with HPLC method according to previously described protocols. ${ }^{(13-15)}$ Fruits glucose, fructose and saccharose were determined with combination of SPE and HPLC techniques. ${ }^{(16)}$ Ferric reducing ability (FRAP) of fasting native plasma (containing uric acid) and non-urate plasma (pre-treated with uricase and catalase) was evaluated according to the method of Benzie and Strain ${ }^{(17)}$ with some modifications. ${ }^{(12)}$ Individual results were obtained from duplicate experiments and were expressed as a concentration of $\mathrm{Fe}^{3+}$ ions reduced into $\mathrm{Fe}^{2+}$ after 3 min of incubation of plasma samples with FRAP reagent. ${ }^{(12)}$

Statistical analysis. Results were expressed as mean $\pm \mathrm{SD}$ and median. ANOVA for repeated observations or Friedman's ANOVA was applied to assess changes in the variables of our interest over time (before, during and after consumption of strawberries) depending on data distribution tested with Shapiro-Wilk $\mathrm{W}$ test. In the presence of significant changes, the post-hoc analyses were done with Scheffe's test or post-hoc analysis for Friedman's ANOVA (multiple comparisons at 2 different timepoints). Differences between groups (strawberry consumers versus control subjects) were assessed using ANOVA for independent variables. A $p$ value of $<0.05$ was considered significant.

\section{Results}

All subjects completed the study and no protocol violations were noted by investigators. Average consumption (calculated on the basis of subjects reports) of vegetables, meat, fats, oils, eggs 
Table 3. Plasma DPPH radical scavenging activity, ferric reducing ability of plasma (FRAP), uric acid levels and total phenolics concentration in fasting plasma and spot morning urine in strawberry consumers (studied group) and in controls over the study period

\begin{tabular}{|c|c|c|c|c|c|c|c|c|}
\hline \multirow{3}{*}{ Variable } & \multirow{3}{*}{$\begin{array}{l}\text { Subject } \\
\text { group }\end{array}$} & \multicolumn{7}{|c|}{ Day of the study } \\
\hline & & \multicolumn{3}{|c|}{ Run-in } & \multicolumn{2}{|c|}{ Strawberry consumption } & \multicolumn{2}{|c|}{ Wash-out } \\
\hline & & 0 & 3 & 6 & 9 & 12 & 15 & 21 \\
\hline \multirow{2}{*}{$\mathrm{Sc} \%$} & Studied & $\begin{array}{c}25.7 \pm 4.9 \\
(24.8)\end{array}$ & $\begin{array}{c}26.2 \pm 5.6 \\
(25.7)\end{array}$ & $\begin{array}{c}26.5 \pm 5.6 \\
(26.0)\end{array}$ & $\begin{array}{c}26.5 \pm 5.1 \\
(25.4)\end{array}$ & $\begin{array}{c}27.1 \pm 5.7 \\
(26.8)\end{array}$ & $\begin{array}{c}26.1 \pm 5.3 \\
(26.8)\end{array}$ & $\begin{array}{c}25.7 \pm 5.1 \\
(24.9)\end{array}$ \\
\hline & Control & $\begin{array}{c}25.6 \pm 6.6 \\
(24.5)\end{array}$ & $\begin{array}{c}25.6 \pm 5.7 \\
(24.9)\end{array}$ & $\begin{array}{c}27.5 \pm 7.0 \\
(26.3)\end{array}$ & $\begin{array}{c}26.4 \pm 6.5 \\
(25.1)\end{array}$ & $\begin{array}{c}25.7 \pm 5.8 \\
(24.9)\end{array}$ & $\begin{array}{c}26.5 \pm 5.5 \\
(25.3)\end{array}$ & $\begin{array}{c}24.1 \pm 6.1 \\
(23.8)\end{array}$ \\
\hline \multirow{2}{*}{ FRAP $(\mu \mathrm{mol} / \mathrm{L})$} & Studied & $\begin{array}{c}1,511 \pm 213 \\
(1,462)\end{array}$ & $\begin{array}{c}1,475 \pm 340 \\
(1,403)\end{array}$ & $\begin{array}{c}1,510 \pm 242 \\
(1,465)\end{array}$ & $\begin{array}{c}1,538 \pm 261 \\
(1,497)\end{array}$ & $\begin{array}{c}1,564 \pm 295 \\
(1,570)\end{array}$ & $\begin{array}{c}1,561 \pm 240 \\
(1,596)\end{array}$ & $\begin{array}{c}1,533 \pm 231 \\
(1,498)\end{array}$ \\
\hline & Control & $\begin{array}{c}1,563 \pm 178 \\
(1,486)\end{array}$ & $\begin{array}{c}1,494 \pm 269 \\
(1,452)\end{array}$ & $\begin{array}{c}1,492 \pm 212 \\
(1,439)\end{array}$ & $\begin{array}{c}1,506 \pm 321 \\
(1,420)\end{array}$ & $\begin{array}{c}1,578 \pm 189 \\
(1,523)\end{array}$ & $\begin{array}{c}1,554 \pm 265 \\
(1,498)\end{array}$ & $\begin{array}{c}1,512 \pm 225 \\
(1,486)\end{array}$ \\
\hline \multirow{2}{*}{$\begin{array}{l}\text { Non-urate FRAP } \\
(\mu \mathrm{mol} / \mathrm{L})\end{array}$} & Studied & $\begin{array}{c}591 \pm 82 \\
(573)\end{array}$ & $\begin{array}{c}618 \pm 91 \\
(586)\end{array}$ & $\begin{array}{c}656 \pm 72 \\
(634)\end{array}$ & $\begin{array}{c}705 \pm 96 \\
(680)\end{array}$ & $\begin{array}{c}650 \pm 108 \\
(651)\end{array}$ & $\begin{array}{c}658 \pm 75 \\
(669)\end{array}$ & $\begin{array}{c}668 \pm 98 \\
(651)\end{array}$ \\
\hline & Control & $\begin{array}{c}608 \pm 69 \\
(545)\end{array}$ & $\begin{array}{c}598 \pm 104 \\
(536)\end{array}$ & $\begin{array}{c}612 \pm 89 \\
(576)\end{array}$ & $\begin{array}{c}583 \pm 112 \\
(545)\end{array}$ & $\begin{array}{c}598 \pm 74 \\
(562)\end{array}$ & $\begin{array}{c}578 \pm 92 \\
(542)\end{array}$ & $\begin{array}{c}586 \pm 77 \\
(549) \\
\end{array}$ \\
\hline \multirow{2}{*}{$\begin{array}{l}\text { Uric acid } \\
\text { (mg/dL) }\end{array}$} & Studied & $\begin{array}{c}4.2 \pm 0.8 \\
(4.1)\end{array}$ & $\begin{array}{c}4.5 \pm 1.3 \\
(4.3)\end{array}$ & $\begin{array}{c}4.9 \pm 1.3 \\
(4.8)\end{array}$ & $\begin{array}{l}4.2 \pm 1.3 \\
(4.0)\end{array}$ & $\begin{array}{l}4.0 \pm 1.5 \\
(3.9)\end{array}$ & $\begin{array}{c}4.2 \pm 1.5 \\
(4.1)\end{array}$ & $\begin{array}{c}4.5 \pm 1.2 \\
(4.4)\end{array}$ \\
\hline & Control & $\begin{array}{c}4.5 \pm 0.7 \\
(4.3)\end{array}$ & $\begin{array}{c}4.4 \pm 0.6 \\
(4.2)\end{array}$ & $\begin{array}{c}4.7 \pm 0.9 \\
(4.5)\end{array}$ & $\begin{array}{c}4.8 \pm 1.2 \\
(4.7)\end{array}$ & $\begin{array}{c}4.6 \pm 1.1 \\
(4.4)\end{array}$ & $\begin{array}{c}4.7 \pm 0.9 \\
(4.6)\end{array}$ & $\begin{array}{c}4.6 \pm 0.9 \\
(4.3)\end{array}$ \\
\hline \multirow{2}{*}{$\begin{array}{l}\text { Plasma TP } \\
(\mathrm{mmol} / \mathrm{L})\end{array}$} & Studied & $\begin{array}{c}0.75 \pm 0.09 \\
(0.71)\end{array}$ & $\begin{array}{c}0.75 \pm 0.08 \\
(0.73)\end{array}$ & $\begin{array}{c}0.74 \pm 0.09 \\
(0.72)\end{array}$ & $\begin{array}{c}0.76 \pm 0.11 \\
(0.73)\end{array}$ & $\begin{array}{c}0.78 \pm 0.08 \\
(0.74)\end{array}$ & $\begin{array}{c}0.79 \pm 0.09 \\
(0.76)\end{array}$ & $\begin{array}{c}0.77 \pm 0.10 \\
(0.75)\end{array}$ \\
\hline & Control & $\begin{array}{l}0.74 \pm 0.13 \\
(0.72)\end{array}$ & $\begin{array}{l}0.74 \pm 0.09 \\
(0.71)\end{array}$ & $\begin{array}{c}0.77 \pm 0.12 \\
(0.74)\end{array}$ & $\begin{array}{c}0.76 \pm 0.11 \\
(0.73)\end{array}$ & $\begin{array}{c}0.80 \pm 0.12 \\
(0.77)\end{array}$ & $\begin{array}{l}0.78 \pm 0.14 \\
(0.74)\end{array}$ & $\begin{array}{c}0.79 \pm 0.13 \\
(0.75)\end{array}$ \\
\hline \multirow{2}{*}{$\begin{array}{l}\text { Urinary TP } \\
\text { (mmol/g of creatinine) }\end{array}$} & Studied & $\begin{array}{c}1.47 \pm 0.55 \\
(1.29)\end{array}$ & $\begin{array}{c}1.02 \pm 0.21 \\
(0.96)\end{array}$ & $\begin{array}{c}1.22 \pm 0.22 \\
(1.12)\end{array}$ & $\begin{array}{c}1.39 \pm 0.35 \\
(1.21)\end{array}$ & $\begin{array}{c}1.45 \pm 0.34 \\
(1.32)\end{array}$ & $\begin{array}{c}1.29 \pm 0.22 \\
(1.16)\end{array}$ & $\begin{array}{c}1.41 \pm 0.35 \\
(1.33)\end{array}$ \\
\hline & Control & $\begin{array}{c}1.31 \pm 0.72 \\
(1.12)\end{array}$ & $\begin{array}{c}1.18 \pm 0.67 \\
(1.02)\end{array}$ & $\begin{array}{c}0.99 \pm 0.22 \\
(0.87)\end{array}$ & $\begin{array}{c}0.85 \pm 0.19 \\
(0.74)\end{array}$ & $\begin{array}{c}1.11 \pm 0.28 \\
(0.82)\end{array}$ & $\begin{array}{c}1.03 \pm 0.22 \\
(0.91)\end{array}$ & $\begin{array}{c}1.07 \pm 0.40 \\
(0.90)\end{array}$ \\
\hline
\end{tabular}

Sc\%, \% of the initial amount of decomposed DPPH radical by deproteinized plasma; TP, total phenolics. After a 6 day run-in period volunteers (studied group, $n=10$ ) started to consume $500 \mathrm{~g}$ of strawberries daily (the first dose on the 6 th day and the last dose on the 14 th day). On the 15 th day, strawberries were withdrawn and subjects entered a wash-out period lasting until the 21st day. Controls ( $n=7)$ did not consume strawberries. Both groups were on semi-restrictive diet (without fruits, nuts, chocolate, coffee, cocoa, wine and beer) over the whole study period. Median value showed in parentheses. No significant changes were found.

and dairy products as well as the self assessed ingested caloric load and number of meals per day did not change in the strawberry consumers as well as in the control group over the study period (data not shown). Daily consumption of tea did not exceed 3 cups in both groups.

Effect of strawberry consumption on fasting plasma DPPH radical scavenging activity. Plasma DPPH radical scavenging activity and uric acid levels were similar in both groups and did not change during the study period (Table 3 ). However, plasma specimens deprived of uric acid revealed significant changes in antioxidant activity in strawberry consumers (Fig. 1). During the run-in period, the mean DPPH radical scavenging activity of non-urate plasma decreased from $6.3 \pm 0.8$; median $6.3 \%$ to $5.7 \pm 0.6$; median $5.7 \%(p<0.01)$ and after the introduction of strawberries to the diet, it rose to a maximal value of $6.6 \pm 0.6$; median $6.5 \%$ on the 9 th day. After 6 days of the wash-out period, the antioxidant activity declined to values observed at the end of the run in period (Fig. 1). In the control group, similar decline (although not significant) of non-urate plasma DPPH radical activity was noted during the run-in period with stable values at the remaining time-points.

Effect of strawberry consumption on ferric reducing ability of plasma (FRAP). Fasting FRAP was similar in strawberry consumers and controls and no within- and between-groups changes were noted during the study period (Table 3 ). Similarly, non-urate FRAP did not differ between controls and strawberry consumers at all time-points. Although mean non-urate FRAP at the 9th day (after 3 days of strawberry consumption) was about 1.2-times higher than that the one at the 0th day, this difference did not reach statistical significance $(p>0.05)$.
Concentrations of selected phenolics in fasting plasma.

The mean concentrations of total plasma phenolics were similar and stable in both groups (Table 3). Urolithin A, ellagic acid, 3.4-dihydroxybenzoic acid and 3-hydroxyhippuric acid were never detected in fasting plasma. Other compounds such as 4hydroxyhippuric acid, dihydrocaffeic acid, caffeic acid, homovanillic acid, vanillic acid, 3,4-dihydroxyphenylacetic acid (Table 4), and hippuric acid (data not shown) were measured. However, their concentrations did not change significantly in strawberry consumers (Table 4) as well as in controls (data not shown) throughout the study period.

Concentration of selected phenolics in spot urine. There were no significant changes in the total concentrations of phenolics in spot urine in strawberry consumers and controls throughout the study period (Table 3 ). The concentration of urolithin A and 4-hydroxyhippuric acid in spot urine were significantly raised in response to the introduction of strawberries to the diet (Fig. 2 and 3). After 3 and 6 days of strawberry consumption, the mean urinary concentration of urolithin A was $9.3-(95.3 \pm 61.7$; median $101.1 \mu \mathrm{mol} / \mathrm{g}$ of creatinine) and 8.7-times higher $(88.3 \pm 63.9$; median $77.3 \mu \mathrm{mol} / \mathrm{g}$ of creatinine $)(p<0.05)$ than that observed in spot urine collected on the 6 th day $(10.2 \pm 31.5$; median $0.0 \mu \mathrm{mol} / \mathrm{g}$ of creatinine) (about $4 \mathrm{~h}$ before the first portion of strawberry was consumed). Although, on the 15th day ( 9 days of strawberry ingestion) urinary urolithin A was 6.5-times higher than that at the end of the run-in period $(66.8 \pm 37.3$; median 63.8 vs $10.2 \pm 31.5$; median $0.0 \mu \mathrm{mol} / \mathrm{g}$ of creatinine), this did not reach statistical significance. Withdrawal of strawberries resulted in a decrease in the urinary levels of urolithin A and at the end of the wash-out, its concentration was practically equal to that of baseline (Fig. 2). Urinary urolithin A levels were low and stable in control subjects. 


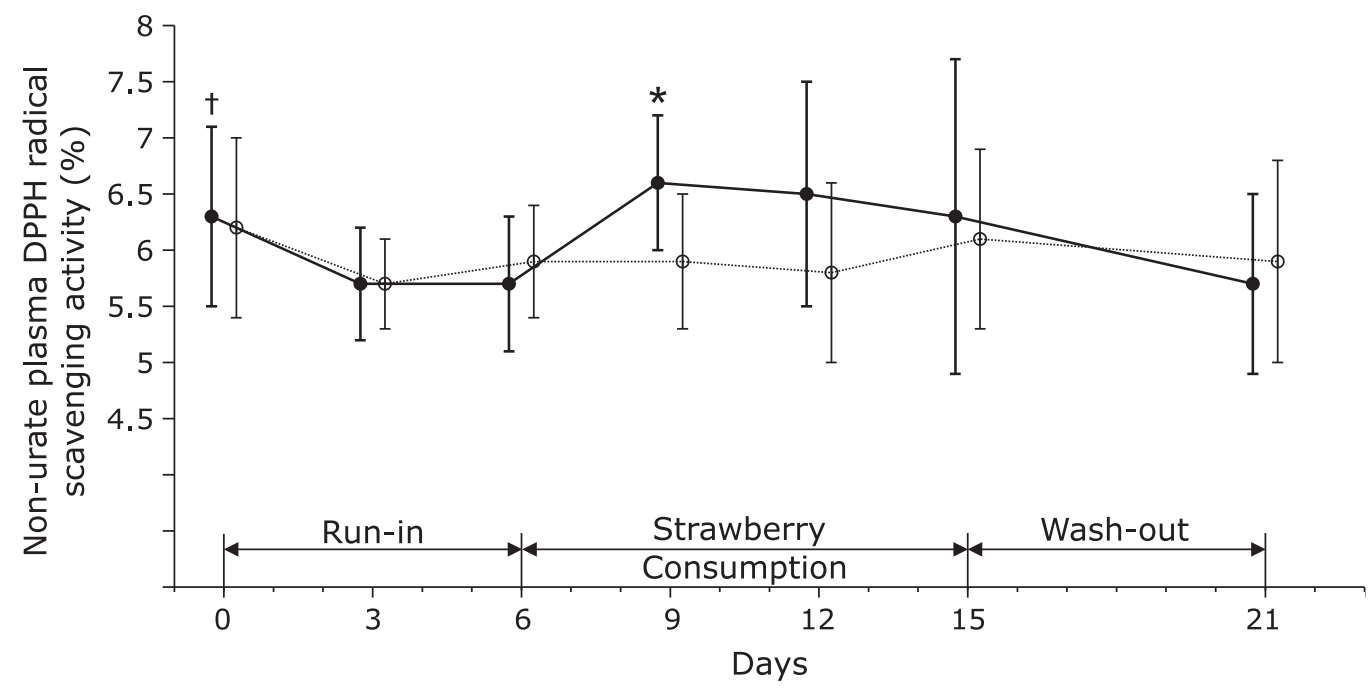

Fig. 1. Effect of strawberry consumption ( $500 \mathrm{~g}$ of fruits daily for 9 days) on the non-urate plasma DPPH radical scavenging activity in healthy subjects (closed circles, $n=10$ ). After a 6 day run-in period volunteers started to consume $500 \mathrm{~g}$ of strawberries daily (the first dose on the 6 th day and the last dose on the 14th day). On the 15th day, strawberries were withdrawn and subjects entered a wash-out period lasting until the 21st day. Control subjects (open circles, $n=7$ ) did not consume strawberries. Fasting plasma samples were treated with uricase and catalase in order to decompose the uric acid. After subsequent deproteinization with acetonitrile the DPPH radical scavenging activity was measured and expressed (mean, SD) as \% of decomposed initial amount of DPPH radical over 30 min incubation. * vs the 3rd, 6th, and 21 st day $-p<0.01,{ }^{+}$vs the 3 rd and 6 th day $-p<0.01$.

Table 4. Concentration of selected phenolic acids in fasting plasma of strawberry consumers over the study period

\begin{tabular}{|c|c|c|c|c|c|c|c|}
\hline \multirow{3}{*}{ Phenolic acid ( $\mu \mathrm{mol} / \mathrm{L})$} & \multicolumn{7}{|c|}{ Day of the study } \\
\hline & \multicolumn{3}{|c|}{ Run-in } & \multicolumn{2}{|c|}{ Strawberry consumption } & \multicolumn{2}{|c|}{ Wash-out } \\
\hline & 0 & 3 & 6 & 9 & 12 & 15 & 21 \\
\hline 4-hydroxyhippuric & $\begin{array}{c}3.87 \pm 3.44 \\
(3.76)\end{array}$ & $\begin{array}{c}3.76 \pm 3.44 \\
(3.65)\end{array}$ & $\begin{array}{c}3.33 \pm 2.79 \\
(3.23)\end{array}$ & $\begin{array}{c}3.44 \pm 3.01 \\
(3.27)\end{array}$ & $\begin{array}{c}3.23 \pm 2.37 \\
(3.12)\end{array}$ & $\begin{array}{c}3.65 \pm 3.12 \\
(3.12)\end{array}$ & $\begin{array}{c}3.65 \pm 3.55 \\
(3.55)\end{array}$ \\
\hline Dihydrocaffeic & $\begin{array}{c}0.13 \pm 0.13 \\
(0.07)\end{array}$ & $\begin{array}{c}0.07 \pm 0.06 \\
(0.04)\end{array}$ & $\begin{array}{c}0.07 \pm 0.05 \\
(0.05)\end{array}$ & $\begin{array}{c}0.10 \pm 0.07 \\
(0.08)\end{array}$ & $\begin{array}{c}0.10 \pm 0.10 \\
(0.06)\end{array}$ & $\begin{array}{c}0.09 \pm 0.09 \\
(0.06)\end{array}$ & $\begin{array}{c}0.08 \pm 0.06 \\
(0.06)\end{array}$ \\
\hline Caffeic & $\begin{array}{c}0.11 \pm 0.07 \\
\quad(0.09)\end{array}$ & $\begin{array}{c}0.08 \pm 0.05 \\
(0.07)\end{array}$ & $\begin{array}{c}0.11 \pm 0.10 \\
(0.09)\end{array}$ & $\begin{array}{c}0.12 \pm 0.11 \\
(0.10)\end{array}$ & $\begin{array}{c}0.11 \pm 0.08 \\
(0.08)\end{array}$ & $\begin{array}{c}0.11 \pm 0.13 \\
(0.09)\end{array}$ & $\begin{array}{c}0.09 \pm 0.05 \\
(0.07)\end{array}$ \\
\hline Homovanillic & $\begin{array}{c}0.27 \pm 0.19 \\
(0.24)\end{array}$ & $\begin{array}{c}0.29 \pm 0.13 \\
(0.20)\end{array}$ & $\begin{array}{c}0.22 \pm 0.11 \\
(0.19)\end{array}$ & $\begin{array}{c}0.32 \pm 0.19 \\
(0.28)\end{array}$ & $\begin{array}{c}0.28 \pm 0.16 \\
(0.26)\end{array}$ & $\begin{array}{c}0.27 \pm 0.10 \\
(0.24)\end{array}$ & $\begin{array}{c}0.28 \pm 0.17 \\
(0.26)\end{array}$ \\
\hline Vanillic & $\begin{array}{c}0.06 \pm 0.07 \\
(0.04)\end{array}$ & $\begin{array}{c}0.03 \pm 0.02 \\
(0.00)\end{array}$ & $\begin{array}{c}0.04 \pm 0.03 \\
(0.00)\end{array}$ & $\begin{array}{c}0.02 \pm 0.03 \\
(0.00)\end{array}$ & $\begin{array}{c}0.05 \pm 0.08 \\
(0.00)\end{array}$ & $\begin{array}{c}0.03 \pm 0.04 \\
(0.00)\end{array}$ & $\begin{array}{c}0.04 \pm 0.06 \\
(0.00)\end{array}$ \\
\hline DOPAC & $\begin{array}{c}3.75 \pm 2.08 \\
\quad(3.54)\end{array}$ & $\begin{array}{c}2.92 \pm 1.46 \\
(2.71)\end{array}$ & $\begin{array}{c}4.17 \pm 3.23 \\
(4.06)\end{array}$ & $\begin{array}{c}4.17 \pm 2.60 \\
(4.08)\end{array}$ & $\begin{array}{c}3.65 \pm 2.29 \\
(3.44)\end{array}$ & $\begin{array}{c}2.60 \pm 1.04 \\
(2.50)\end{array}$ & $\begin{array}{c}4.27 \pm 1.77 \\
(4.06)\end{array}$ \\
\hline
\end{tabular}

DOPAC, 3,4-dihydroxyphenylacetic acid. After a 6 day run-in period volunteers started to consume $500 \mathrm{~g}$ of strawberries daily (the first dose on the 6 th day and the last dose on the 14th day). On the 15th day, strawberries were withdrawn and subjects entered a wash-out.

At the 9th and 12th day they reached $0.63 \pm 1.21$; median 0.0 and $0.34 \pm 0.56$; median $0.0 \mu \mathrm{mol} / \mathrm{g}$ of creatinine and were significantly lower $(p<0.05)$ than those in strawberry consumers (Fig. 2). During the run-in period, the mean concentration of 4-hydroxyhippuric acid decreased about 2.5-times (79.2 \pm 95.9 ; median $43.5 \mu \mathrm{mol} / \mathrm{g}$ of creatinine on day 0 vs $31.3 \pm 32.3$; median $27.2 \mu \mathrm{mol} / \mathrm{g}$ of creatinine on the 6 th day). When volunteers began ingesting strawberries, the urinary levels of 4-hydroxyhippuric acid rose, reaching a maximal value after 6 days $(185.4 \pm 130.2$; median $146.8 \mu \mathrm{mol} / \mathrm{g}$ of creatinine) then significantly decreased despite the ingestion of fruits (15th day). There were significant differences $(p<0.05)$ in urinary levels of 4-hydroxyhippuric acid between strawberry consumers and controls at the 9th and 12th day (Fig. 3). In like manner to urolithin A, the concentration of 4-hydroxyhippuric acid decreased during the wash-out period until values were similar to those noted at the end of the run-in period. The concentration of chlorogenic acid at the end of the study was significantly lower from that of the 0th and 9th day among strawberry consumers (Table 5). Urinary concentrations of hipuric acid, dihydrocaffeic acid, caffeic acid, vanillic acid, homovanillic acid, 3,4-dihydroxyphenylacetic acid and 3hydroxyhippuric acid were stable in controls (data not shown) and did not change in response to strawberry consumption (Table 5). Ellagic acid was never detected in any spot urine sample. The vast majority of urine samples obtained from strawberry consumers were negative for the presence of 3,4-dihydroxybenzoic acid. This compound was only detected in 8 samples: 2 on the 0 th, 1 sample on the $3 \mathrm{rd}$, 9th and 12 th day and in 3 samples on the 15 th day, respectively. The concentration of 3,4-dihydroxybenzoic acid ranged from 20.9 to $137.1 \mu \mathrm{mol} / \mathrm{g}$ of creatinine.

\section{Discussion}

Daily consumption of $500 \mathrm{~g}$ of strawberries for 9 days did not 


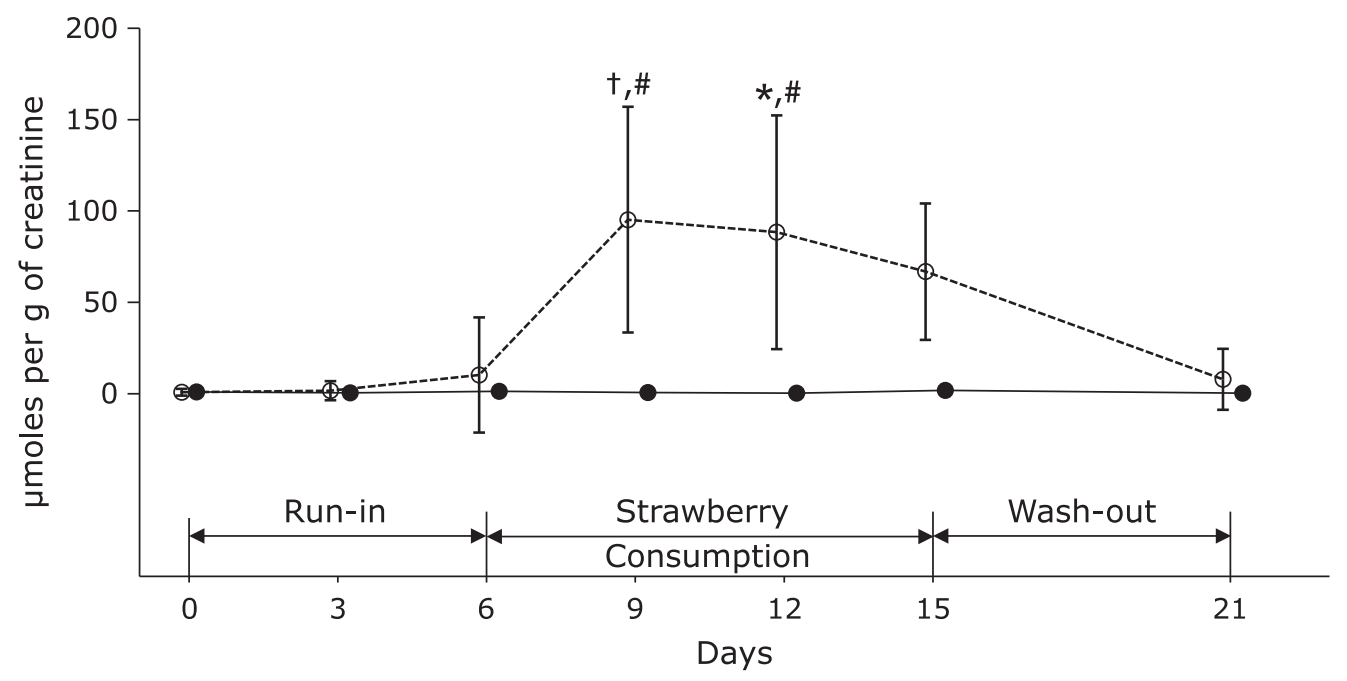

Fig. 2. Effect of strawberry consumption ( $500 \mathrm{~g}$ of fruits per day for 9 days) on the concentrations of urolithin $\mathrm{A}$ (open circles) in morning spot urine of healthy subjects $(n=10)$. Control subjects (closed circles, $n=7$ ) did not consume strawberries. Results $($ mean \pm SD) are expressed in $\mu$ mol/g of creatinine. Other details as for Fig. $1 .{ }^{\dagger}$ vs the 0 th, 3rd and 6th day within strawberry group $-p<0.05, *$ vs the 0 th, 3rd, 6th and 21 st day within strawberry group $-p<0.05, "$ vs corresponding value of controls (the 9 th and 12 th day) $-p<0.05$.

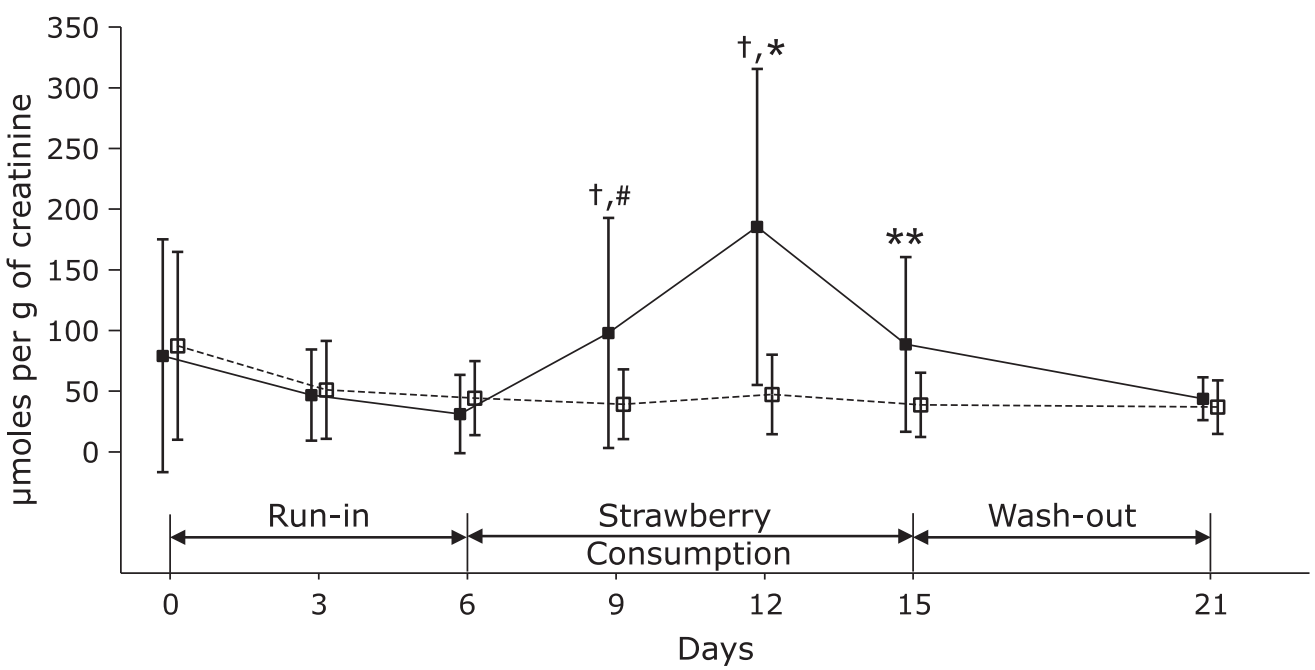

Fig. 3. Effect of strawberry consumption ( $500 \mathrm{~g}$ of fruits per day for 9 days) on the concentrations of 4-hydroxyhippuric acid (closed squares) in morning spot urine of healthy subjects $(n=10)$. Control subjects (open squares, $n=7)$ did not consume strawberries. Results (mean \pm SD) are expressed in $\mu \mathrm{mol} / \mathrm{g}$ of creatinine. Other details as for Fig. $1 .{ }^{*}$ vs the 0 th, 3rd, 6 th and 21 st day $-p<0.05$, * vs the 6 th day- $p<0.05, * *$ vs the 12 th day $-p<0.05$ within the strawberry group, respectively. ${ }^{+}$vs corresponding value of controls (the 9 th and 12 th day) $-p<0.05$.

increase the concentration of every phenolic studied in fasting plasma. To the exclusion of everything else, the concentration of urolithin $\mathrm{A}$ and 4-hydroxyhippuric acid were raised significantly in spot urine after strawberry intake. Despite the stable levels of phenolics, samples of fasting plasma deprived of uric acid revealed a significant increase in the DPPH radical scavenging activity in response to strawberry consumption. Contrary to this, the antioxidant activity (DPPH test and FRAP) of native (untreated with uricase) fasting plasma specimens did not change over the study period. Moreover, the non-urate FRAP did not alter significantly after consumption of strawberries. In addition, control subjects that did not consume strawberries had stable antioxidant activity (DPPH test and FRAP) of both native and non-urate plasma samples. This implies that diet supplementation with strawberries was the cause of augmentation of non-urate plasma ability to decompose the DPPH radical in the studied group. Analysis of plasma samples deprived of uric acid (nonurate plasma) is an approach that increases the sensitivity of monitoring dietary interventions on antioxidant activity in blood. ${ }^{(18)}$ Uric acid contributes considerably to the plasma antioxidant activity. ${ }^{(11,18)}$ Moreover, plasma antioxidant activity expressed as the ability to decompose the DPPH radical or FRAP strongly correlated with urate levels. ${ }^{(12)}$ In addition, positive linear correlation between FRAP and plasma DPPH radical scavenging activity was observed in healthy subjects. ${ }^{(11)}$ Therefore, uric acid can mask any augmentation in the antioxidant potential related to a moderate increase in circulating low molecular weight antioxidants.

Bearing this in mind, one may expect that since strawberries induced increase in non-urate DPPH radical scavenging activity, this would be accompanied by the augmentation of non-urate 
Table 5. Concentration of selected phenolic acids in spot morning urine of strawberry consumers over the study period

\begin{tabular}{|c|c|c|c|c|c|c|c|}
\hline \multirow{3}{*}{$\begin{array}{l}\text { Phenolic acid } \\
\text { ( } \mu \mathrm{mol} / \mathrm{g} \text { of creatinine) }\end{array}$} & \multicolumn{7}{|c|}{ Day of the study } \\
\hline & \multicolumn{3}{|c|}{ Run-in } & \multicolumn{2}{|c|}{ Strawberry consumption } & \multicolumn{2}{|c|}{ Wash-out } \\
\hline & 0 & 3 & 6 & 9 & 12 & 15 & 21 \\
\hline Hippuric ${ }^{\#}$ & $\begin{array}{l}5.8 \pm 5.9 \\
(2.0)\end{array}$ & $\begin{array}{l}2.1 \pm 2.3 \\
(1.1)\end{array}$ & $\begin{array}{l}2.6 \pm 3.0 \\
\quad(1.3)\end{array}$ & $\begin{array}{l}3.7 \pm 4.1 \\
\quad(2.3)\end{array}$ & $\begin{array}{l}2.2 \pm 0.9 \\
(2.2)\end{array}$ & $\begin{array}{l}1.9 \pm 0.8 \\
(2.1)\end{array}$ & $\begin{array}{l}1.7 \pm 0.7 \\
(1.8)\end{array}$ \\
\hline Chlorogenic & $\begin{array}{c}10.7 \pm 9.4 \\
(13.7)\end{array}$ & $\begin{array}{l}6.6 \pm 6.4 \\
\quad(7.5)\end{array}$ & $\begin{array}{l}7.1 \pm 8.6 \\
\quad(7.9)\end{array}$ & $\begin{array}{l}9.2 \pm 5.9 \\
(13.8)\end{array}$ & $\begin{array}{l}5.9 \pm 2.1 \\
\quad(7.1)\end{array}$ & $\begin{array}{l}5.2 \pm 2.7 \\
\quad(7.6)\end{array}$ & $\begin{array}{l}3.9 \pm 2.0 * \\
\quad(5.3)\end{array}$ \\
\hline Dihydrocaffeic & $\begin{array}{l}8.8 \pm 9.7 \\
(4.7)\end{array}$ & $\begin{array}{l}8.2 \pm 9.7 \\
\quad(3.3)\end{array}$ & $\begin{array}{l}6.4 \pm 5.6 \\
\quad(5.0)\end{array}$ & $\begin{array}{l}9.1 \pm 9.5 \\
\quad(6.8)\end{array}$ & $\begin{array}{c}9.2 \pm 11.2 \\
(5.3)\end{array}$ & $\begin{array}{c}11.8 \pm 12.3 \\
(9.5)\end{array}$ & $\begin{array}{l}7.3 \pm 6.8 \\
(6.2)\end{array}$ \\
\hline Caffeic & $\begin{array}{l}7.9 \pm 7.1 \\
\quad(5.7)\end{array}$ & $\begin{array}{l}4.3 \pm 4.2 \\
\quad(3.6)\end{array}$ & $\begin{array}{l}7.1 \pm 6.4 \\
\quad(4.3)\end{array}$ & $\begin{array}{l}10.0 \pm 10.7 \\
(7.1)\end{array}$ & $\begin{array}{l}16.4 \pm 24.3 \\
(7.9)\end{array}$ & $\begin{array}{c}12.1 \pm 14.3 \\
(4.3)\end{array}$ & $\begin{array}{l}6.4 \pm 5.0 \\
\quad(4.3)\end{array}$ \\
\hline Caffeic & $\begin{array}{l}7.9 \pm 7.1 \\
(5.7)\end{array}$ & $\begin{array}{l}4.3 \pm 4.2 \\
\quad(3.6)\end{array}$ & $\begin{array}{c}7.1 \pm 6.4 \\
(4.3)\end{array}$ & $\begin{array}{c}10.0 \pm 10.7 \\
(7.1)\end{array}$ & $\begin{array}{c}16.4 \pm 24.3 \\
(7.9)\end{array}$ & $\begin{array}{c}12.1 \pm 14.3 \\
(4.3)\end{array}$ & $\begin{array}{l}6.4 \pm 5.0 \\
(4.3)\end{array}$ \\
\hline Vanillic & $\begin{array}{c}19.4 \pm 15.7 \\
(14.8)\end{array}$ & $\begin{array}{c}6.6 \pm 5.4 \\
(4.9)\end{array}$ & $\begin{array}{c}11.2 \pm 13.1 \\
(5.2)\end{array}$ & $\begin{array}{c}8.4 \pm 6.7 \\
(7.3)\end{array}$ & $\begin{array}{c}7.5 \pm 5.1 \\
(6.4)\end{array}$ & $\begin{array}{c}12.7 \pm 11.6 \\
(7.0)\end{array}$ & $\begin{array}{c}20.9 \pm 28.1 \\
(9.3)\end{array}$ \\
\hline DOPAC & $\begin{array}{c}78.3 \pm 39.9 \\
(68.7)\end{array}$ & $\begin{array}{c}70.0 \pm 31.1 \\
(56.0)\end{array}$ & $\begin{array}{c}79.2 \pm 42.5 \\
(65.7)\end{array}$ & $\begin{array}{c}69.9 \pm 28.3 \\
\quad(68.3)\end{array}$ & $\begin{array}{c}72.3 \pm 32.2 \\
(69.5)\end{array}$ & $\begin{array}{c}59.2 \pm 19.0 \\
(63.2)\end{array}$ & $\begin{array}{c}91.6 \pm 28.7 \\
(93.9)\end{array}$ \\
\hline 3-hydroxyhippuric & $\begin{array}{c}161.3 \pm 161.9 \\
(90.4)\end{array}$ & $\begin{array}{c}37.2 \pm 30.1 \\
(36.6)\end{array}$ & $\begin{array}{c}49.8 \pm 73.1 \\
(20.1)\end{array}$ & $\begin{array}{c}103.3 \pm 107.9 \\
(56.3)\end{array}$ & $\begin{array}{c}89.6 \pm 91.1 \\
(45.8)\end{array}$ & $\begin{array}{c}71.0 \pm 53.9 \\
(46.4)\end{array}$ & $\begin{array}{c}67.3 \pm 85.7 \\
(29.6)\end{array}$ \\
\hline
\end{tabular}

DOPAC, 3,4-dihydroxyphenylacetic acid. After a 6 day run-in period volunteers started to consume $500 \mathrm{~g}$ of strawberries daily (the first dose on the 6 th day and the last dose on the 14th day). On the 15th day, strawberries were withdrawn and subjects entered a wash-out period lasting until the 21 st day. Other details as for Table 3 . " results expressed in mmol/g of creatinine. * vs day $0-p<0.05$ and vs day 9 th- $p<0.01$. Changes of $3-$ hydroxyhippuric acid over the study period were on the border of significance $(p=0.057)$.

FRAP. However, the non-urate FRAP did not alter significantly in strawberry consumers.

The mean contribution of uric acid to FRAP and plasma activity to decompose the DPPH radical in strawberry consumers group at the 0 th day was $61 \%$ and $75 \%$, respectively, as derived from data shown in Table 3 and Fig. 1. Therefore, even mild increase in circulating antioxidants could augment to a greater extent the nonurate plasma DPPH radical scavenging activity than the non-urate FRAP. This could be a plausible explanation of the different effect of strawberry consumption on the non-urate plasma antioxidant activity measured with DPPH test and FRAP method. On the other hand, this may result just from different principles of these two methods for assessment of plasma antioxidant capacity: reaction with stable free radical in the case of DPPH test and reduction of $\mathrm{Fe}^{3+}$ ions in the FRAP assay.

Although fasting levels of polyphenols did not alter from baseline, it is possible that strawberry ingestion transiently elevated circulating phenolics. Vanillic acid, 4-hydroxybenzoic acid and 3,4-dihydroxybenzoic acid peaked in plasma within $3 \mathrm{~h}$ after a single consumption of $750 \mathrm{~g}$ of strawberries in healthy subjects. ${ }^{(9)}$ Similar results were noted after a dose of $300 \mathrm{~g}$ of fruits with normalization in the levels of phenolics within 6 additional hours. ${ }^{(19)}$ These can spare the low molecular weight antioxidants in plasma and thus probably cause a moderate rise in the fasting nonurate plasma DPPH radical scavenging activity. We used relatively unspecific analytical methods (HPLC-UV/VIS and HPLCECD) for selected phenolics determination in plasma and urine samples. Application of HPLC with mass spectrometric detection gives opportunity to identify and measure much more phenolic metabolites related to strawberry intake. Therefore, it can not be excluded that some phenolics rose in fasting plasma after strawberry intake and enhanced its non-urate antioxidant activity measured with the DPPH test. Daily ingestion of ascorbic acid with strawberry consumption was about $214 \mathrm{mg}$. Since in vitro ascorbic acid can decompose the DPPH radical, ${ }^{(11)}$ this could lead to an augmentation in the plasma antioxidant activity in vivo. Although we did not monitor plasma ascorbic acid levels, previous clinical trials concerning the effect of this vitamin on antioxidant activity rather excludes explanation. Plasma FRAP did not change significantly after ingestion of a single dose of $500 \mathrm{mg}$ of ascorbic acid in healthy subjects. ${ }^{(20)}$ Similarly, an oral dose of $1,200 \mathrm{mg}$ of ascorbic acid did not change FRAP $4 \mathrm{~h}$ post ingestion, nevertheless, enzymatic removal of uric acid revealed a significant increment (about 12\%) in the antioxidant activity in a group of five healthy volunteers. ${ }^{(18)}$ In our study, the dose of vitamin $C$ ingested with a portion of strawberry was 2.5- and 5.6-times lower than that of the previously described experiments and fasting plasma was collected at least $18 \mathrm{~h}$ after the consumption of fruits. It would therefore seem that, the increase in ascorbic acid was not a direct culprit of strawberry-induced augmentation in non-urate plasma DPPH radical scavenging activity.

Six day wash-out decreased the non-urate plasma antioxidant activity to a baseline value in the strawberry consumers. This and especially no changes in FRAP disagrees with the observation of elevated fasting plasma FRAP after a 1 month wash-out preceded by a 16-day daily consumption of $500 \mathrm{~g}$ of strawberries. ${ }^{(5)}$ Moreover, this study described significant FRAP increase (by $8.5 \%$ ) already after 4 days of fruits intake that was also elevated for the remaining days of diet supplementation with strawberries (the 8th, 12th and 16th day). ${ }^{(5)}$ The specific study protocol of Tulipani et al. ${ }^{(5)}$ report may explain these discrepancies: A-during the 10 -day pre-study and 16-day strawberry consumption periods subjects were on a restrictive low polyphenolics diet (without fruit and vegetables, jams, nuts, honey, chocolate and cocoa derivatives, wine, beer, tea, fruit juices), and under such restrictions one may expect a stronger effect of strawberries on plasma antioxidant activity; B-they did not measure non-urate FRAP, and at the end of the wash-out period plasma uric acid levels were elevated by approximately $5.4 \%$ from baseline, probably being the cause for the increased FRAP at this time-point; $\mathrm{C}$ - they rather used over-optimistic statistical method (just the Wilcoxon paired samples test) for data analysis. The study protocol and obtained data in that study could be recognized as repeated measures design. ${ }^{(21)}$ These data should be analyzed with proper statistical tools in order to assess changes in the variables over time, and secondly, in case of significance, to compare values at two different time-points with appropriate post-hoc tests.

Although majority of phenolic metabolites related to the ingestion of a single dose of strawberries were excreted in the urine within several hours ${ }^{(22,23)}$ we observed increased concentrations of urolithin A and 4-hydroxyhippuric acid in spot morning urine of strawberry consumers. Dietary polyphenols are transformed 
into less complex compounds by the gut microflora before absorption into the bloodstream. (24) 3,4-dihydroxybenzoic acid and 4-hydroxybenzoic acid are the products of the microbial conversion of cyanidin and pelargonidin, respectively. ${ }^{(22,24)}$ Ellagitannins and ellagic acid are metabolized to urolithin A and B. ${ }^{(19,23)}$ 4-hydroxybenzoic acid can undergo glycination in the liver to form 4-hydroxyhippuric acid which can be subsequently excreted in the urine. ${ }^{(25)}$ Based on Table 1, daily ingestion of pelargonidin molecules with a portion of strawberries were about 90-times higher than that of cyanidin. This may explain why the concentration of 4-hydroxyhippuric acid in spot urine rose significantly in response to strawberry consumption, whereas the levels of 3,4dihydroxybenzoic acid were only occasionally detected in a few samples. The molar content of ellagic acid in strawberries was the second highest after pelargonidin, explaining the elevated excretion of urolithin A with spot urine.

Although our subjects were on semi-restrictive diet (allowing consumption of vegetables but no fruits and polyphenols rich beverages), we did not observe any significant changes of total phenolics concentration in plasma and spot urine. Therefore, it seems that positive effect of strawberry consumption on non-urate fasting plasma antioxidant activity measured with DPPH test could be achieved in subjects without any dietary restrictions. However, this requires further studies.

In conclusion, we found that $500 \mathrm{~g}$ of daily strawberry consumption raised the fasting non-urate plasma DPPH radical scavenging in healthy subjects. This may decrease the risk of systemic

\section{References}

1 Basu A, Wilkinson M, Penugonda K, Simmons B, Betts NM, Lyons TJ. Freeze-dried strawberry powder improves lipid profile and lipid peroxidation in women with metabolic syndrome: baseline and post intervention effects. Nutr J 2009; 28: 43.

2 Basu A, Fu DX, Wilkinson M, et al. Strawberries decrease atherosclerotic markers in subjects with metabolic syndrome. Nutr Res 2010; 30: 462-469.

3 Henning SM, Seeram NP, Zhang Y, et al. Strawberry consumption is associated with increased antioxidant capacity in serum. J Med Food 2010; 13: $116-122$

4 Jenkins DJ, Nguyen TH, Kendall CW, et al. The effect of strawberries in a cholesterol-lowering dietary portfolio. Metabolism 2008; 57: 1636-1644.

5 Tulipani S, Alvarez-Suarez JM, Busko F, et al. Strawberry consumption improves plasma antioxidant status and erythrocyte resistance to oxidative haemolysis in humans. Food Chem 2011; 128: 180-186.

6 Aaby K, Ekeberg D, Skrede G. Characterization of phenolic compounds in strawberry (Fragaria $\mathrm{x}$ ananassa) fruits by different HPLC detectors and contribution of individual compounds to total antioxidant capacity. J Agric Food Chem 2007; 55: 4395-4406.

7 Zhang Y, Seeram NP, Lee R, Feng L, Heber D. Isolation and identification of strawberry phenolics with antioxidant and human cancer cell antiproliferative properties. J Agric Food Chem 2008; 56: 670-675.

8 Azzini E, Vitaglione $\mathrm{P}$, Intorre $\mathrm{F}$, et al. Bioavailability of strawberry antioxidants in human subjects. Br J Nutr 2010; 104: 1165-1173.

9 Russell WR, Scobbie L, Labat A, Duthie GG. Selective bio-availability of phenolic acids from Scottish strawberries. Mol Nutr Food Res 2009; 53: S85S91.

10 Felgines C, Talavéra S, Gonthier MP, et al. Strawberry anthocyanins are recovered in urine as glucuro- and sulfoconjugates in humans. J Nutr 2003; 133: $1296-1301$.

11 Chrzczanowicz J, Gawron A, Zwolinska A, et al. Simple method for determining human serum 2,2-diphenyl-1-picryl-hydrazyl (DPPH) radical scavenging activity - possible application in clinical studies on dietary antioxidants. Clin Chem Lab Med 2008; 46: 342-349.

12 Godycki-Cwirko M, Krol M, Krol B, et al. Uric acid but not apple polyphenols is responsible for the rise of plasma antioxidant activity after apple juice consumption in healthy subjects. $J$ Am Coll Nutr 2010; 29: 397-406.

13 Kennedy JA, Jones GP. Analysis of proanthocyanidin cleavage products following acid-catalysis in the presence of excess phloroglucinol. J Agric imbalance between oxidants and anti-oxidants and be one of the mechanisms of health-promoting effect of this fruit consuming.

\section{Acknowledgments}

This work was supported by a research grant from the EU Regional Development Fund through the Polish Innovation Economy Operational Program, contract N. UDAPOIG. 01.03.0110-109/08-00.

\section{Abbreviations}

ANOVA analysis of variance

DOPAC 3,4-dihydroxyphenylacetic acid

DPPH 2,2-diphenyl-1-picrylhydrazyl radical

ECD electrochemical detection

EDTA ethylenediaminetetraacetic acid

FRAP ferric reducing ability of plasma

HPLC high-performance liquid chromatography

LDL low-density lipoprotein

$\mathrm{PE} \quad$ polyethylene

$\mathrm{Sc} \% \quad$ plasma scavenging effect

SPE solid phase extraction

\section{Conflict of Interest}

No potential conflicts of interest were disclosed.
4 Oszmiański J, Wojdylo A. Comparative study of phenolic content and antioxidant activity of strawberry puree, clear and cloudy juices. Eur Food Res Technol 2009; 228: 623-631.

15 Oszmiański J, Wojdylo A, Kolniak J. Effect of L-ascorbic acid, sugar, pectin and freeze-thaw treatment on polyphenols content of frozen strawberries. LWT Food Science and Technology 2009; 42: 581-586.

16 Fruit and Vegetable Juices. Determination of Glucose, Fructose, Sorbitol and Sucrose Contents. Method using High-Performance Liquid Chromatography. BS EN 12630; 1999.

17 Benzie IF, Strain JJ. The ferric reducing ability of plasma (FRAP) as a measure of "antioxidant power": the FRAP assay. Anal Biochem 1996; 239: 70-76.

18 Rabovsky A, Cuomo J, Eich N. Measurement of plasma antioxidant reserve after supplementation with various antioxidants in healthy subjects. Clin Chim Acta 2006; 371: 55-60.

19 Cerdá B, Espín JC, Parra S, Martínez P, Tomás-Barberán FA. The potent in vitro antioxidant ellagitannins from pomegranate juice are metabolised into bioavailable but poor antioxidant hydroxy-6H-dibenzopyran-6-one derivatives by the colonic microflora of healthy humans. Eur J Nutr 2004; 43: 205 220.

20 Choi SW, Benzie IF, Collins AR, Hannigan BM, Strain JJ. Vitamins C and E: acute interactive effects on biomarkers of antioxidant defense and oxidative stress. Mutat Res 2004; 551: 109-117.

21 Altman DG. Practical Statistics for Medical Research. Chapman \& Hall/ CRC, 1999; 327-331.

22 Vitaglione P, Donnarumma G, Napolitano A, et al. Protocatechuic acid is the major human metabolite of cyanidin-glucosides. J Nutr 2007; 137: 2043 2048.

23 Cerdá B, Tomás-Barberán FA, Espín JC. Metabolism of antioxidant and chemopreventive ellagitannins from strawberries, raspberries, walnuts, and oak-aged wine in humans: identification of biomarkers and individual variability. J Agric Food Chem 2005; 53: 227-235.

24 Aura AM. Microbial metabolism of dietary phenolic compounds in the colon. Phytochem Rev 2008; 7: 407-429.

25 Beyoğlu D, Idle JR. The glycine deportation system and its pharmacological consequences. Pharmacol Ther 2012; 135: 151-167. 